\title{
Relationship between fatness and puberty in Black Indigenous and SA Landrace gilts
}

\author{
P.C. Coetzee and N.H. Casey \\ Department of Animal and Wildlife Sciences, University of Pretoria, Pretoria 0002, South Africa
}

\begin{abstract}
In a $2 \times 2$ factorial design, attainment of puberty in 32 Black Indigenous (BI) and 60 SA Landrace (SAL) gilts was studied under the effects of two treatment diets fed individually ad libitum. Treatment 1 contained 160 g CP and 13.6 MJ DE/kg DM, and Treatment 2, a 25\% dilute of Treatment 1 using wood shavings, contained $120 \mathrm{~g} \mathrm{CP}$ and $10.2 \mathrm{MJ}$ DE/kg DM. Target weights set for BI gilts were from 10 to $50 \mathrm{~kg}$ and for SAL, 15 to $120 \mathrm{~kg}$. A sample was slaughtered at each target weight. Reproductive organs were removed, measured and the number, size and physiological state of follicles recorded. Carcasses were deboned and the soft tissue analysed for moisture, protein and fat content. Treatments affected growth significantly. Cumulative mass (lnkg) was regressed against cumulative ME intake (lnME) with b the allometric coefficient in a linear autoregressive model. A change in b indicated a change or breakpoint of physiological development. Puberty was taken to coincide with the breakpoint. Age and weight at puberty differed by treatment for each genotype. Estimated live weight fat (percentage) and carcass fat (percentage) at these ages show a close range between genotypes and treatment diets.
\end{abstract}

Keywords: Sexual maturity, fat percentage, growth manipulation, onset of puberty

\#Corresponding author. E-mail: norman.casey@up.ac.za

\section{Introduction}

Physical growth and physiological development of animals are linked and interdependent. Nutrition is the primary exogenous determinant of the rate of growth of gross tissue depots (bone, muscle, adipose tissue and total body lipid reserves) and organs, and the concomitant attainment of sexual maturity. The growth of gross tissue depots and organs occur in allometric relationships that can be defined into phases (Roux, 1976; Roux \& Kemm, 1981). The quantity and quality of nutrition within a growth phase can affect the rate of change in the body's relationships and the development of different tissues and organs (Roux, 1974). The emphasis in modern meat animals is on muscle accretion with a minimum of fat. Fat accretion is a natural phenomenon of growth and development and in humans and rats (Frisch, 1980), and pigs (Den Hartog \& Van Kampen, 1980) fat content may affect the onset of puberty. Fat deposition is a function of both nutrition and physiological development and total body fat can be used to evaluate an animal's physical development (Casey, 1982). Animals need to reach a specific target mass-for-age to attain a measure of maturity (Kempster et al., 1982). The Black Indigenous pigs' target weights are $110 \mathrm{~kg}$ for boars and $60 \mathrm{~kg}$ for sows (Mason \& Maule, 1960). The SA Landrace target weight is $350 \mathrm{~kg}$ for boars and $240 \mathrm{~kg}$ for sows.

This paper examines the relationship between fatness and puberty in gilts.

\section{Materials and Methods}

The trial was a $2 \times 2$ factorial design with two pig genotypes and two treatment diets (TD). The pigs were the non-genetically improved, characteristically early maturing, Black Indigenous (BI) and the genetically improved for production traits, SA Landrace (SAL). Diets were: TD1: $160 \mathrm{~g}$ CP and 13.6 MJ DE/kg DM, and TD2: 120 g CP and 10.2 MJ DE/kg DM (Table 1). Gilts, 60 SAL and 32 BI, were randomly allocated at weaning to the TD1 and TD2 and target weights (TW) by genotype. Weight gain and cumulative ME intake (CMEI) were monitored. Feeding was ad libitum to TW. The TW for the BI gilts were 10, 15, 20, 25, 30, 40 and $50 \mathrm{~kg}$, and for the SAL gilts 15, 20, 25, 30, 40, 50, 60, 70, 80, 90, 100, 110 and $120 \mathrm{~kg}$. Two animals per target weight per feeding level were allocated since, due to the linearity of the model, no multiple data points need to be set in an allometric-autoregressive model (Belt et al., 1991). Housing was in individual pens $\left(6 \mathrm{~m}^{2}\right)$ in a well-ventilated, enclosed house with natural light. A ration of $13.5 \mathrm{ME} / \mathrm{kg}$ and $180 \mathrm{~g} \mathrm{CP} / \mathrm{kg}$ was fed up to six weeks of age, and thereafter the respective treatment diets ad libitum. 
Table 1 Composition of treatment diets containing 160 and 120 g crude protein/kg feed fed to gilts to determine the effect of diet on sexual maturity

\begin{tabular}{lcc}
\hline \multicolumn{1}{c}{ Ingredients } & Treatment diet 1 & Treatment diet 2 \\
\hline Gross energy, MJ/kg & 16.9 & 17.0 \\
ME, MJ ME/kg & 13.6 & 10.2 \\
Crude protein, g/kg & 160 & 120 \\
Fat, g/kg & 47 & 36 \\
Lysine, g/kg & 9 & 7 \\
Wood shavings \% & 0.0 & 25.0 \\
\hline
\end{tabular}

Treatment 1 diet (TD1) was a standard commercial feed (160 g CP/kg). TD2 was a 25\% dilute of TD1 by adding milled pine wood shavings to TD1 (Roux \& Kemm, 1981). Feed was withdrawn at TW for $24 \mathrm{~h}$ before slaughter to obtain an empty body weight (EBW). No antibiotics or growth promoters were administered and no medication was required other than Triatix ${ }^{\circledR}$ monthly to control mites.

The pigs were slaughtered in the conventional manner and the intact carcasses were depilated. The carcasses were opened down the ventral line and the gastro intestinal tract, lungs, heart, trachea and reproductive organs removed. Reproductive organs were separated and weighed. Oviducts were dissected loose, the entire reproductive system placed on a flat surface and the length measured from the vagina past the cervix along the uterus to the left and right oviducts, respectively. Ovaries were weighed separately and the follicle size (mm diameter) and follicle number noted. The head was removed by severing between the first vertebra and the scull and warm dressed carcass weight recorded. Carcasses were chilled for $24 \mathrm{~h}$ at $4{ }^{\circ} \mathrm{C}$ after which cold carcass weight was recorded. Carcasses were halved by cutting through the middle of the spinal cord. Kidney fat and reproductive tract fat was dissected out and weighed. The carcasses were then sectioned, deboned, the muscle and fat separated, and the weight of each gross tissues component recorded. Fat and muscle were respectively milled with a $4 \mathrm{~mm}$ sieve mixed and a $100 \mathrm{~g}$ samples freeze-dried at 30 millitor, $60{ }^{\circ} \mathrm{C}$ for $36 \mathrm{~h}$. These were mixed in a blender, bottled and stored at $-14{ }^{\circ} \mathrm{C}$. Thawed samples were later analysed for fat, protein and moisture content following procedures (AOAC, 1980).

Graphic metrical and chemical datasets were developed and phases of development identified by an allometric-outoregression procedure (Roux \& Kemm, 1981). Transformed data was collated by the equation $\mathrm{Y}=\mathrm{a}+\mathrm{bX}$ where $\mathrm{Y}=\operatorname{In}$ (dependent variable) $\mathrm{X}=\operatorname{In}$ (Cumulative ME intake) and $\mathrm{b}=$ allometric coefficient (Roux et al., 1982). Difference between inclines (b) was tested by analysis of covariance and a t-test. Data was developed on pooled regression analyses and smallest quadratic covariance analyses. Physiological and reproductive maturities were plotted and analysed by using the QUATTRO PRO ${ }^{\circledR}$ and STATGRAPHICS ${ }^{\circledR}$ V5 programmes. Stepwise linear regression was applied.

\section{Results and Discussions}

The average TW, age (d) and CMEI of SAL and BI gilts on two dietary treatments (160 and $120 \mathrm{~g}$ $\mathrm{CP} / \mathrm{kg})$ are shown in Table 2. LW and empty LW in all age groups differed $(\mathrm{P}<0.05)$ as from the second TW. Carcass and moisture, protein and carcass fat weights $(\mathrm{kg})$ differed $(\mathrm{P}<0.05)$ between genotypes and age groups (Table 3). Non-fat carcass fraction had increased isometrically when compared with EBW. In contrast, carcass fat weight grew at different rates $(\mathrm{P}<0.05)$ to EBW, as reported by Walstra $(1980)$.

An autoregressive linear analysis of digestible energy intake against age showed a breakpoint at the ages shown in Table 4. This is a physiological breakpoint at similar physiological age, but at different chronological ages, live weights and carcass weights (Table 4), as was reported by Roux \& Kemm (1981). The estimated LW fat (\%) and carcass fat (\%) at these ages (Table 4) show a close range between genotypes and treatment diets. Treatment diets affected the age at which the break occurred $(\mathrm{P}<0.01)$ with the lower $120 \mathrm{~g} \mathrm{CP} / \mathrm{kg}$ diet having delayed the reaching of this physiological breakpoint. 
Table 2 Average target weight (TW, kg), age (d), cumulative feed intake (CFI) and cumulative metabolisable energy intake (CMEI) of SA Landrace and Black Indigenous gilts on two dietary treatments containing 160 and $120 \mathrm{~g} \mathrm{CP} / \mathrm{kg}$

\begin{tabular}{|c|c|c|c|c|c|c|c|c|c|c|c|}
\hline \multicolumn{6}{|c|}{ Black Indigenous gilts } & \multicolumn{6}{|c|}{ SA Landrace gilts } \\
\hline \multicolumn{3}{|c|}{$\begin{array}{l}\text { Treatment Diet } 160 \mathrm{~g} \\
\mathrm{CP} / \mathrm{kg}\end{array}$} & \multicolumn{3}{|c|}{$\begin{array}{c}\text { Treatment Diet } 120 \mathrm{~g} \\
\mathrm{CP} / \mathrm{kg}\end{array}$} & \multicolumn{3}{|c|}{$\begin{array}{l}\text { Treatment Diet } 160 \mathrm{~g} \\
\mathrm{CP} / \mathrm{kg}\end{array}$} & \multicolumn{3}{|c|}{$\begin{array}{c}\text { Treatment Diet } 120 \mathrm{~g} \\
\mathrm{CP} / \mathrm{kg}\end{array}$} \\
\hline TW & Age & CFI & TW & Age & CMEI & TW & Age & CFI & TW & Age & CMEI \\
\hline 10.2 & 48.0 & 7.0 & 10.3 & 49.0 & 7.0 & 15.1 & 50.0 & 6.9 & 15.1 & 49.0 & 6.8 \\
\hline 15.1 & 63.0 & 28.4 & 15.3 & 74.0 & 47.4 & 19.6 & 59.0 & 18.1 & 20.0 & 76.0 & 38.2 \\
\hline 20.5 & 76.0 & 49.1 & 20.6 & 97.0 & 102.3 & 25.4 & 73.0 & 34.4 & 24.9 & 91.0 & 68.0 \\
\hline 24.8 & 87.0 & 65.8 & 25.2 & 105.0 & 129.3 & 31.4 & 81.0 & 49.4 & 30.1 & 108.0 & 103.1 \\
\hline 31.1 & 100.0 & 96.4 & 30.1 & 122.0 & 176.4 & 40.6 & 97.0 & 75.7 & 40.9 & 123.0 & 133.4 \\
\hline 40.0 & 114.0 & 141.2 & 14.3 & 154.0 & 246.2 & 51.4 & 109.0 & 108.3 & 50.0 & 145.0 & 201.3 \\
\hline \multirow[t]{7}{*}{50.8} & 140.0 & 187.9 & 50.0 & 184.0 & 313.1 & 60.5 & 122.0 & 139.1 & 61.4 & 169.0 & 254.3 \\
\hline & & & & & & 70.1 & 135.0 & 177.5 & 68.8 & 181.0 & 307.1 \\
\hline & & & & & & 81.0 & 153.0 & 223.6 & 81.6 & 200.0 & 366.8 \\
\hline & & & & & & 90.4 & 165.0 & 269.6 & 91.3 & 225.0 & 426.7 \\
\hline & & & & & & 100.9 & 188.0 & 322.3 & 99.9 & 241.0 & 484.9 \\
\hline & & & & & & 109.6 & 207.0 & 362.7 & 111.3 & 72.0 & 539.8 \\
\hline & & & & & & 120.3 & 226.0 & 421.9 & 119.4 & 296.0 & 607.0 \\
\hline
\end{tabular}

Table 3 Carcass $(\mathrm{CW})$, moisture $\left(\mathrm{H}_{2} \mathrm{O}\right)$, protein and fat weights $(\mathrm{kg})$ of Black Indigenous and SA Landrace gilts on two treatment diets containing 120 and $160 \mathrm{~g} \mathrm{CP} / \mathrm{kg}$

\begin{tabular}{|c|c|c|c|c|c|c|c|c|c|c|c|c|c|c|c|}
\hline \multicolumn{8}{|c|}{ Black Indigenous gilts } & \multicolumn{8}{|c|}{ SA Landrace gilts } \\
\hline \multicolumn{4}{|c|}{ Treatment diet 160 g CP/kg } & \multicolumn{4}{|c|}{ Treatment diet 120 g CP/kg } & \multicolumn{4}{|c|}{ Treatment diet $160 \mathrm{~g} \mathrm{CP} / \mathrm{kg}$} & \multicolumn{4}{|c|}{ Treatment diet 120 g CP $/ \mathrm{kg}$} \\
\hline CW & $\mathrm{H}_{2} \mathrm{O}$ & Protein & Fat & $\mathrm{CW}$ & $\mathrm{H}_{2} \mathrm{O}$ & Protein & Fat & $\mathrm{CW}$ & $\mathrm{H}_{2} \mathrm{O}$ & Protein & Fat & $\mathrm{CW}$ & $\mathrm{H}_{2} \mathrm{O}$ & Protein & Fat \\
\hline 6.4 & 4.0 & 1.3 & 1.2 & 6.6 & 4.0 & 1.2 & 1.3 & 9.7 & 5.9 & 2.4 & 1.5 & 9.7 & 5.7 & 2.4 & 1.5 \\
\hline 9.9 & 5.8 & 2.0 & 1.8 & 9.8 & 5.2 & 1.8 & 2.8 & 12.4 & 7.3 & 2.7 & 2.4 & 12.8 & 7.0 & 3.1 & 2.4 \\
\hline 13.2 & 7.7 & 2.2 & 3.4 & 13.7 & 7.7 & 2.3 & 3.7 & 16.6 & 9.1 & 3.8 & 3.6 & 16.2 & 8.3 & 3.8 & 3.9 \\
\hline 16.7 & 9.2 & 3.0 & 4.4 & 16.7 & 9.3 & 2.7 & 4.6 & 20.8 & 11.0 & 5.4 & 4.3 & 19.7 & 10.6 & 4.6 & 4.5 \\
\hline 21.2 & 11.4 & 3.8 & 5.9 & 20.4 & 10.3 & 3.2 & 6.9 & 27.2 & 14.5 & 6.2 & 6.5 & 27.0 & 13.5 & 6.1 & 6.9 \\
\hline 28.2 & 13.9 & 5.2 & 8.9 & 28.5 & 13.6 & 4.7 & 10.0 & 35.1 & 18.3 & 7.8 & 8.9 & 33.5 & 17.8 & 6.3 & 9.4 \\
\hline \multirow[t]{7}{*}{36.8} & 17.1 & 6.0 & 13.6 & 35.2 & 15.5 & 5.4 & 14.4 & 41.8 & 20.6 & 9.8 & 11.5 & 42.1 & 19.7 & 9.3 & 12.8 \\
\hline & & & & & & & & 50.7 & 24.6 & 11.3 & 14.9 & 48.5 & 22.3 & 10.1 & 16.5 \\
\hline & & & & & & & & 59.5 & 27.3 & 14.0 & 18.2 & 58.7 & 26.0 & 12.7 & 20.0 \\
\hline & & & & & & & & 66.4 & 29.1 & 15.0 & 22.1 & 67.1 & 27.4 & 14.9 & 24.4 \\
\hline & & & & & & & & 75.6 & 32.9 & 17.6 & 25.0 & 73.5 & 30.4 & 16.0 & 26.9 \\
\hline & & & & & & & & 81.7 & 34.7 & 18.4 & 18.7 & 81.8 & 32.8 & 18.0 & 30.6 \\
\hline & & & & & & & & 90.5 & 37.0 & 19.1 & 34.4 & 89.5 & 34.0 & 18.2 & 36.9 \\
\hline
\end{tabular}

Ovarian development increased in BI gilts on TD1 $160 \mathrm{~g}$ CP/kg between days 55 and 90, while the TD2 120 g CP/kg group showed delayed ovarian development. The observation was similar in the SAL gilts where ovarian development increased rapidly between 80 and 120 days of age in gilts on TD1 $160 \mathrm{~g} \mathrm{CP} / \mathrm{kg}$ diet. Follicle development as an indicator of puberty, occurred in the BI gilts on TD1 $160 \mathrm{~g}$ CP around days 100 - 114 (Table 5). The gilts on TD2 120 g CP had slightly delayed follicle development around days 102 120. In the SAL the same trend was observed with the gilts on the TD1 $160 \mathrm{~g}$ CP having follicle development between days 153 - 165 and those on TD2 $120 \mathrm{~g} \mathrm{CP}$, follicle development between days 181 - 200. Dietary treatment had a significant effect $(\mathrm{P}<0.05)$ on the appearance of follicles. 
Table 4 Estimated age of breakpoints and estimated percentage live weight fat and carcass fat according to treatment diet (160 and $120 \mathrm{~g} \mathrm{CP} / \mathrm{kg}$ ) in Black Indigenous and SA Landrace gilts

\begin{tabular}{lcccc}
\hline & \multicolumn{2}{c}{ Black Indigenous gilts } & \multicolumn{2}{c}{ SA Landrace gilts } \\
\cline { 2 - 5 } Treatment diet/kg & $160 \mathrm{~g} \mathrm{CP}$ & $120 \mathrm{~g} \mathrm{CP}$ & $160 \mathrm{~g} \mathrm{CP}$ & $120 \mathrm{~g} \mathrm{CP}$ \\
\hline \multirow{2}{*}{ Age (d) } & 80 & 102 & 90 & 115 \\
Live weight fat (\%) & 17.2 & 18.2 & 15 & 16 \\
Carcass fat (\%) & 28.1 & 28.5 & 30.6 & 32.6 \\
\hline
\end{tabular}

Table 5 Follicle size and type up to $30 \mathrm{~kg}$ and from $40 \mathrm{~kg}$ live weight and at corresponding age (d) according to treatment diet (120 and $160 \mathrm{~g} \mathrm{CP} / \mathrm{kg}$ ) by genotype, Indigenous and SA Landrace gilts

\begin{tabular}{|c|c|c|c|c|}
\hline Genotype & $\begin{array}{c}\text { Treatment } \\
\text { diet }\end{array}$ & $\begin{array}{l}\mathrm{LW} \\
\mathrm{Kg}\end{array}$ & $\begin{array}{c}\text { Age } \\
\text { d }\end{array}$ & Follicles \\
\hline \multirow[t]{4}{*}{ Black Indigenous gilts } & 160 g CP & Up to 30 & $100(+-4)$ & $2-6 \mathrm{~mm}$ \\
\hline & & From 40 & $114(+-3)$ & 2-6 mm, Graafian, Corpus luteum \\
\hline & 120 g CP & UP to 25 & $105(+-2)$ & $2-6 \mathrm{~mm}$ \\
\hline & & From 30 & $154(+-3)$ & 2-6 mm, Graafian, Corpus luteum \\
\hline \multirow{4}{*}{ SA Landrace gilts } & 160 g CP & Up to 80 & $152(+-2)$ & $2-8 \mathrm{~mm}$ \\
\hline & & From 90 & $165(+-1)$ & 2-8 mm, Graafian,Corpus luteum \\
\hline & 120 g CP & Up to 70 & $181(+-1)$ & $2-8 \mathrm{~mm}$ \\
\hline & & From 80 & $200(+-1)$ & 2-8 mm, Graafian,Corpus luteum \\
\hline
\end{tabular}

\section{Conclusions}

Sexual maturity as identified by first oestrous is determined by the presence and physiological state of ovarian follicles that occurs at different ages and live weights in different pig genotypes due to genetic differences in mature size and growth rate. It appears that puberty is reached within a close range of body fatness even if growth had been restricted by nutritional influences.

\section{Acknowledgements}

The authors acknowledge S. Greaves and H. Lucht for their technical assistance.

\section{References}

A.O.A.C., 1980. Official methods of analysis, $13^{\text {th }}$ edition. Association of Official Analytical Chemists, Washington DC.

Belt, M.J., Casey, N.H. \& Smith, G.A., 1992. The description of poultry development: An allometicautoregressive approach. Br. Poult. Sci. 33, 279-288.

Casey, N.H., 1982. Carcass and growth characteristics of four South African sheep breeds and Boer Goat. D.Sc. (Agric) thesis, University of Pretoria, Pretoria, South Africa.

Den Hartog, L.A. \& Van Kampen, G.J.M., 1980. Relation between nutrition and fertility in pigs. Neth. J. Agric. Sci. 28, 211-227.

Frisch, R.E., 1980. Pubertal adipose tissue: is it necessary for normal sexual maturation? Evidence from the rat and human female. Fed. Proc. 39, 2395-400.

Kempster, A.J., Cuthertson, A. \& Harrington, G., 1982. Carcass Evaluation in Livestock Breeding, Production and Marketing. Granda Publishing Ltd. London.

Mason, I.L. \& Maule, J.P., 1960. The Indigenous Livestock of Eastern and Southern Africa. C.A.B. Publ. no 14, University Press, Aberdeen.

Quatro Pro ${ }^{\circledR}$ Statistical Spreadsheet of Corel WordPerfect Office. Corel Corporation, www.corel.com .

Roux, C.Z., 1974. The relationship between growth and feed intake. Agroanimalia 6, 49-52. 
Roux, C.Z., 1976. A model for the description and regulation of growth and production. Agroanimalia 8, 83-94.

Roux, C.Z. \& Kem, E.H., 1981. The influence of dietary energy on a mathematical model for growth, body composition and feed utilization of pigs. S. Afr. J. Anim. Sci. 11, 255-268.

STAGRAPHICS $^{\circledR}$ V5. STATPOINT TECHNOLOGIES, INC. 560 Broadview Avenue, Suite 201, Warrenton, Virginia 20186, www.statgraphics.com .

Walstra, P., Bergstrom, P.L. \& Mateman, G., 1983. Effects on the distribution of fat deposition. In: Fat Quality in Lean Pigs. Ed. Wood, J.D., AFRC Meat Research Institute, Bristol, UK. pp. 117-125. 